\title{
Rectificatif
}

Suite à une erreur d'imposition, veuillez remplacer les pages 425 à 434 des Annales de Zootechnie, 1981, 30 (4), par le présent article.

\section{Lamb fattening in cages or on straw litter $\left({ }^{*}\right)$}

\author{
M. MANFREDINI, C. CAVANI and P. LENZI \\ Istituto di Alimentazione Animale \\ Università di Bologna \\ Via S. Giacomo, 11, 40126 Bologna, Italia
}

\section{Summary \\ Lamb fattening in cages or on straw litter}

The trial was conducted on thirty-six Suffolk $\mathrm{x}$ Apennine fattening lambs divided into six groups of six animals each. Three groups were traditionally reared on straw litter and three in slotted-floor cages. The animals averaged $15 \mathrm{~kg}$ at the beginning and approximately $35 \mathrm{~kg}$ at the end of the trial. Slotted-floor cages when compared to on-straw-litter confinement system did not affect daily gain, feed intake and feed efficiency nor they affected carcass traits and composition. Caged animals presented a higher dressing percentage and a higher weight of metacarpi. These results were discussed.

\section{1. - Introduction}

The rearing systems used in lamb fattening are continually changing. One of the principal goals of the introduction of modern technology is to save manpower. For this purpose the slatted floor, constructed with different materials, has been tested in pens and in cages (AREhART et al., 1969 ; Dimitrov et al., 1973 ; CzerNeck \& PilarczyK, 1977 ; Nygaard, 1978 ; Dirmundsson, 1978 ; Westendorp, 1978).

The use of cages in lamb fattening offers many advantages if compared with traditional straw deep litter in that they a) eliminate bedding costs (i.e. costs related. to purchase, transport, storage and distribution of straw or other materials); b) require less labour for manure removal; c) reduce space requirements per animal; d) offer clean, dry floor; e) contribute to lamb comforts in hot weather; f) provide better control of parasites (Watson, 1962 ; Mansfield, Lewis \& McKibBen, 1967). The object of the present experiment is to study the effect of two different rearing systems on fattening lamb performance : fattening in cages and on traditional straw deep litter.

(*) Research carried out in reference to the Progetto Finalizzato del C.N.R. : Incremento delle disponibilita alimentari di origine animale. The present research was in collaboration with the C.R.P.A. (Research Center on Animal Production - Via Crispi, 3 - Reggio Emilia) with partial grant of Regione Emilia Romagna, II Department-Agriculture and Nutrition. 


\section{2. - Material and methods}

Thirty-six Suffolk x Apennine crossbred lambs were used. The animals were divided into 6 groups of 6 individuals each. Three groups were raised on straw litter and three in slotted floor cages. Within each group the lambs were equalized for sex, single or twin lambing, weight and age. They were weaned at 42 days on average, then kept under observation for 5 days before starting the experiment, in order to detect eventual weaning stress and control their adaptability to the new experimental diet.

\section{TABLE 1}

Composition of the diet

Composition du régime

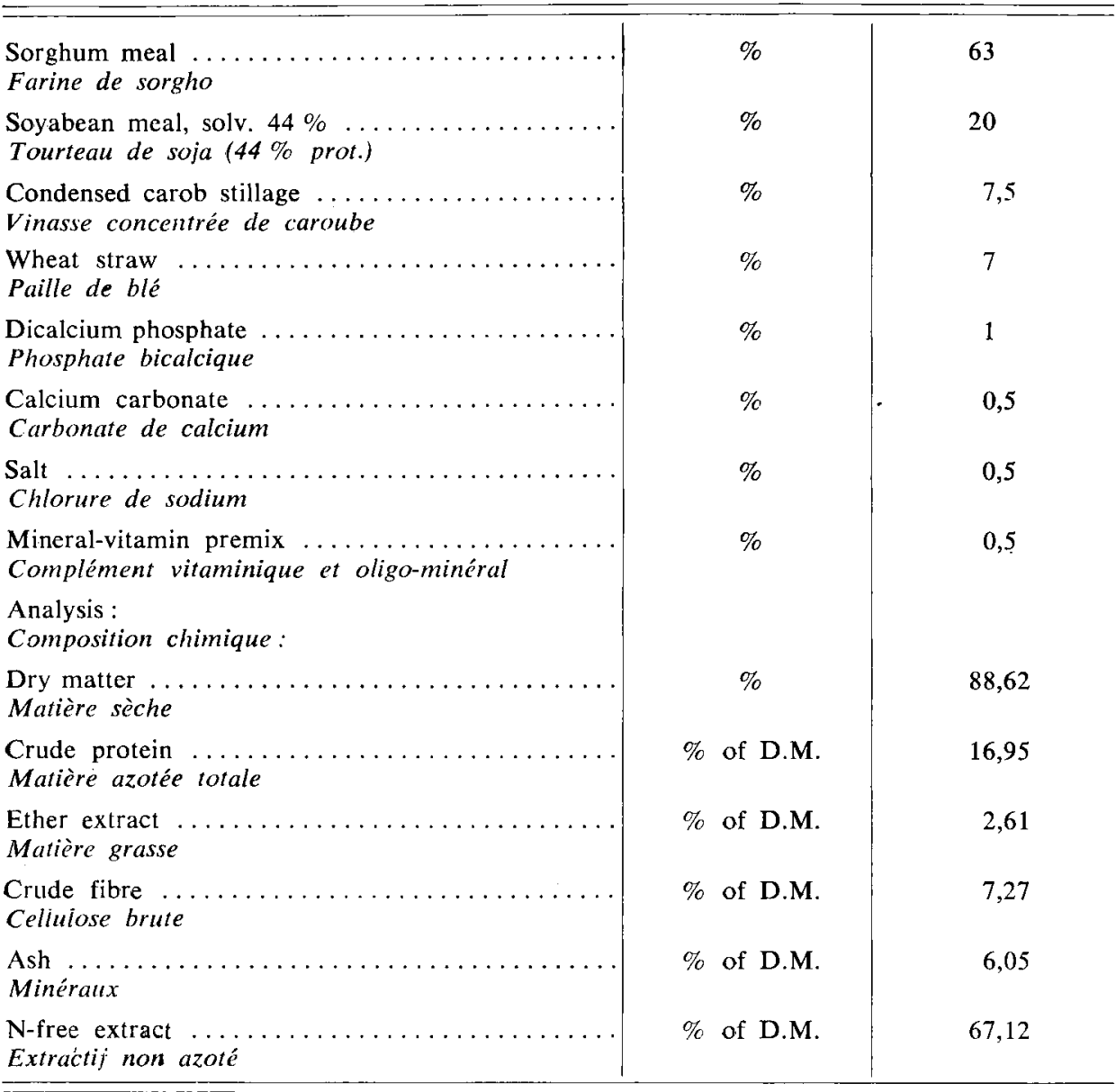




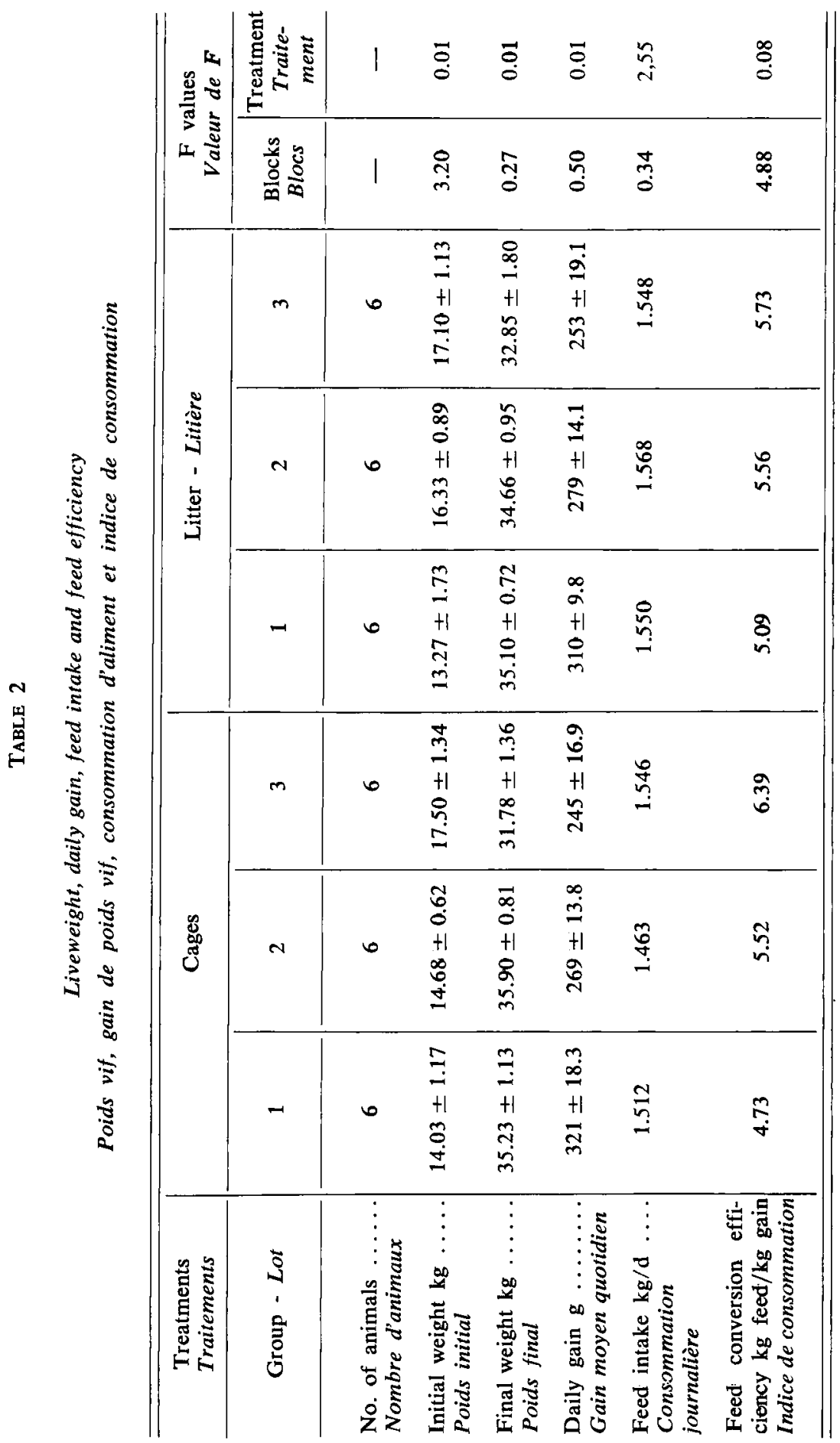


The experiment was not begun on the same day for all animals, owing to the difficulty to have 36 suitable subjects simultaneously. The experiment was divided into three successive periods using 12 lambs at a time (two groups). The number 1, 2, 3 are used in Table 2 to indicate the successive groups of lambs used in the experiment.

The cáges were made of $200 \times 120 \times 125 \mathrm{~cm}$ metal sections. The space allowance per animal was therefore $0.40 \mathrm{~m}^{2}$. The slotted floors were built from grid sections of $5 \mathrm{~mm}$ electro-welded zinc-coated steel slats and $0.8 \times 5.5 \mathrm{~cm}$ openings. This results in the floors of the cages having a ratio of 56 p. 100 empty space and 44 p. 100 solid surface. Each cage was fitted with a self-feeder on the smaller side and an automatic drinking bowl.

For lambs reared on straw litter, the ground area was $200 \times 170 \mathrm{~cm}^{2}$, i.e. $0.56 \mathrm{~m}^{2}$ per animal. The litters were made up of finely ground straw and were distributed daily in proper amounts so as to avoid the possibility that it might be consumed as food. The lambs were fed ad libitum with a concentrate meal mixture, the chemical composition of which is found in Table 1. Weight gain and feed intake were measured at 21 day intervals. Only male animals were slaughtered for study. These were slaughtered when they reached $35 \mathrm{~kg}$ of liveweight, after 14 hours of fasting.

Carcass measurements were made according to BocCard, Dumont \& PeYron (1964). Complete dissection of right sides was made on the basis of the suggestions of BOCCARD \& DUMONT (1955). The health of the animals were checked daily throughout the experiment to find out clinical symptoms of disease and once again at slaughter by anatomo-pathological examination.

The results were statistically analyzed by analysis of variance and covariance. As concerns data in Table 2, a randomized block experimental design was used.

\section{3. - Results and discussion}

\section{a) Liveweight gain, feed intake and feed efficiency}

Table 2 shows that weight gain, feed intake and consequently feed efficiency were not affected by the different rearing systems. The present findings are in agreement with those of american researches reported by the Midwest Plan Service (1976) and with those of MACKo (1976). Similar results were also found by TodoROWSKI, RISTESKI \& SALEV (1977) in an experiment conducted on fattening lambs confined in cages, 5 lambs per cage, for two months.

Conversely, marked differences among the different groups within a same treatment were observed. The groups first placed on test presented weight gains superior to those placed on test later. This phenomenon was observed with both rearing systems. It can be related to the changes in environmental conditions during the experimental period. In fact, the increased number of animals - other lambs were accomodated in the same building together with the experimental ones - as well as the poor ventilation led to a rise in relative humidity and ammonia concentration in the building. 


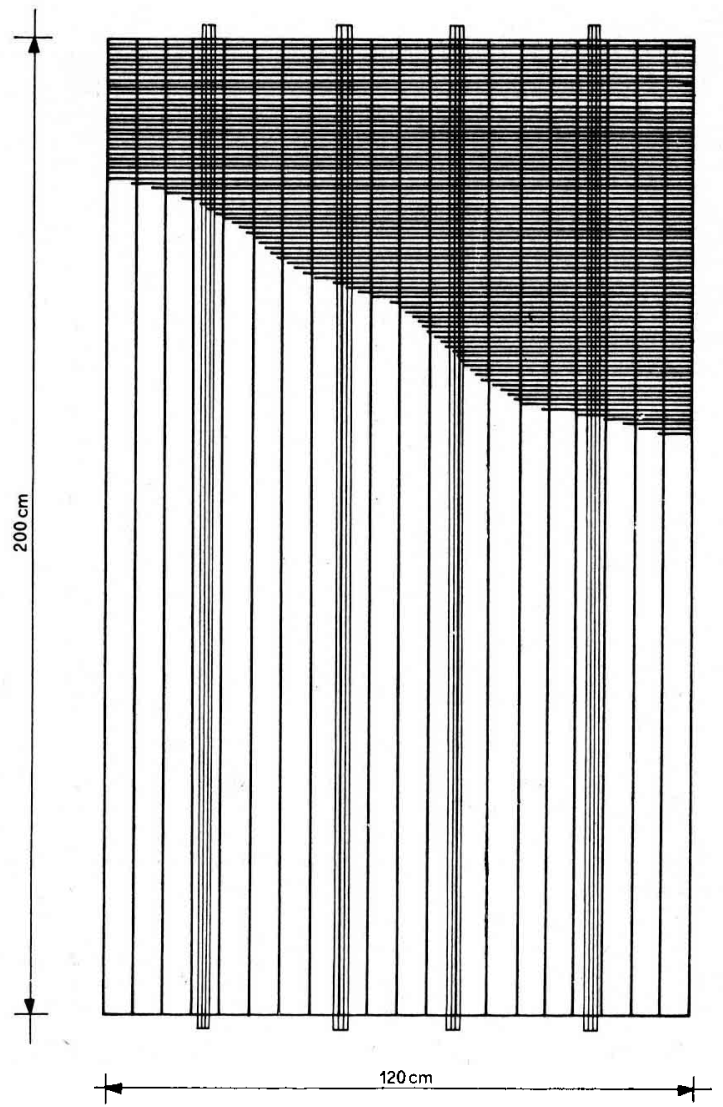

FIG. 1

Sketch of the type of floor used in the cages Type de plancher utilisé dans les cages

\section{b) Slaughter data}

(Table 3) - Dressing percentages, determined both on liveweight and empty body weight, were higher in cage reared lambs. This was mainly due to the higher weight of pelt in the lambs reared on deep litter and attributable to the poorer cleanliness on fleeces.

Also the weight of metacarpi was higher in caged lambs. According to BocCARD \& DuMONT (1976) the weight of metacarpi is linked to the development of the skeleton. In this case, however, it is reasonable to assume that the higher development of metacarpi in caged animals is due to the greater stress exerted on the lambs by this kind of floor.

In fact, the research of HoraK \& Novotny (1977) shows that lambs reared on slatted floor spend more time standing, during the day, than those reared on litter (the difference being about three hours). No significant differences were recorded for the other parameters studied. 
TABLE 3

Slaughter data

Résultats à l'abattage

\begin{tabular}{|c|c|c|c|}
\hline & Cages & $\begin{array}{l}\text { Litter } \\
\text { Litière }\end{array}$ & $\begin{array}{c}\mathrm{t} \text { values } \\
\text { Valeurs de }\end{array}$ \\
\hline $\begin{array}{l}\text { No. of animals } \ldots \ldots \ldots \ldots \ldots \ldots \ldots \\
\text { Nombre d'animaux }\end{array}$ & 9 & 9 & \\
\hline $\begin{array}{l}\text { Liveweight } \mathrm{kg} \ldots \ldots \ldots \ldots \ldots \ldots \ldots \ldots \\
\text { Poids vif }\end{array}$ & $35.01 \pm 0.83$ & $34.98 \pm 0.74$ & 0.04 \\
\hline $\begin{array}{l}\text { Empty liveweight } \mathrm{kg} \ldots \ldots \ldots \ldots \ldots \ldots \\
\text { Poids vif vide }\end{array}$ & $32.01 \pm 0.70$ & $31.78 \pm 0.60$ & 0.25 \\
\hline $\begin{array}{l}\text { Carcass weight } \mathrm{kg} \ldots \ldots \ldots \ldots \ldots \ldots \\
\text { Poids de carcasse }\end{array}$ & $17.33 \pm 0.40$ & $16.45 \pm 0.45$ & 1.45 \\
\hline $\begin{array}{l}\text { Carcass wt/live wt } \% \text {.................. } \\
\text { Poids de carcasse/Poids vif }\end{array}$ & $49.52 \pm 0.32$ & $47.03 \pm 0.69$ & $3.38 * *$ \\
\hline $\begin{array}{l}\text { Carcass wt/empty live wt } \% \ldots \ldots \ldots \\
\text { Poids de carcasse/Poids vif vide }\end{array}$ & $54.14 \pm 0.42$ & $51.74 \pm 0.80$ & $2.76^{*}$ \\
\hline $\begin{array}{l}\text { Head (with skin) } \mathrm{g} \ldots \ldots \ldots \ldots \ldots \ldots \\
\text { Tête (avec peau) }\end{array}$ & $1917 \pm 36.7$ & $1832 \pm 69.5$ & 1.11 \\
\hline $\begin{array}{l}\text { Pelt } g(\ldots \ldots \ldots \ldots \ldots \ldots \ldots \ldots \\
\text { Peau (avec laine) }\end{array}$ & $4520 \pm 192.8$ & $5157 \pm 238.9$ & 2.10 \\
\hline $\begin{array}{l}\text { Feet } \mathrm{g} \ldots \ldots \ldots \ldots \ldots \ldots \ldots \ldots \ldots \ldots \ldots \\
\text { Pieds }\end{array}$ & $1025 \pm 28.4$ & $979 \pm 39.4$ & 0.98 \\
\hline $\begin{array}{l}\text { Liver } g \ldots \ldots \ldots \ldots \ldots \ldots \ldots \ldots \ldots \\
\text { Foie }\end{array}$ & $679 \pm 21.4$ & $657 \pm 36.1$ & 0.52 \\
\hline $\begin{array}{l}\text { Trachea, lungs, heart, spleen } \mathrm{g} \ldots \ldots \ldots \\
\text { Trachée, poumons, cou ur, rate }\end{array}$ & $1021 \pm 31.9$ & $916 \pm 40.7$ & 2.05 \\
\hline $\begin{array}{l}\text { Testes and scrotum } g \ldots \ldots \ldots \ldots \ldots \\
\text { Testicules et scrotum }\end{array}$ & $147 \pm 15.5$ & $143 \pm 14.5$ & 0.19 \\
\hline $\begin{array}{l}\text { Alimentary tract (empty) } \mathrm{g} \ldots \ldots \ldots \ldots \\
\text { Tube digestif vide }\end{array}$ & $3472 \pm 155$ & $3603 \pm 128.6$ & 0.67 \\
\hline $\begin{array}{l}\text { Metacarpi } g \ldots \ldots \ldots \ldots \ldots \ldots \ldots \ldots \\
\text { Métacarpes }\end{array}$ & $117 \pm 3.3$ & $104 \pm 3.2$ & $3.04 * *$ \\
\hline
\end{tabular}


TABLE 4

Carcass measurements

Mensurations de la carcasse

\begin{tabular}{|c|c|c|c|c|}
\hline $\begin{array}{l}\text { Symbol } \\
\text { Symbole }\end{array}$ & & Cages & $\begin{array}{l}\text { Litter } \\
\text { Litière }\end{array}$ & $\begin{array}{c}\mathrm{t} \text { values } \\
\text { Valeurs de } t\end{array}$ \\
\hline & $\begin{array}{l}\text { No. of animals } \ldots \ldots \ldots \ldots \ldots \\
\text { Nombre d'animaux }\end{array}$ & 9 & 9 & - \\
\hline L & $\begin{array}{l}\text { Length (from pubic symphysis to } \\
\text { the first rib) cm ............ } \\
\text { Longueur de la carcasse depuis le } \\
\text { bord antérieur de la symphyse } \\
\text { pubienne jusqu'au milieu du } \\
\text { bord apparent de la première } \\
\text { côte }\end{array}$ & $60.23 \pm 0.65$ & $59.79 \pm 0.65$ & 0.47 \\
\hline $\mathbf{K}$ & $\begin{array}{l}\text { Length (from base of the tail to } \\
\text { base of the neck) cm ......... } \\
\text { Longueur de la carcasse de la } \\
\text { base de la queue a la base du } \\
\text { cou }\end{array}$ & $59.28 \pm 0.06$ & $58.56 \pm 0.92$ & 0.65 \\
\hline$G$ & $\begin{array}{l}\text { Rump width (at the coxal articu- } \\
\text { lation level) } \mathrm{cm} . \ldots \ldots \ldots \ldots \\
\text { Plus grande largeur de la carcasse } \\
\text { au niveau des trochanters }\end{array}$ & $24.60 \pm 0.56$ & $23.91 \pm 0.67$ & 0.80 \\
\hline $\mathrm{Wr}$ & $\begin{array}{l}\text { Maximum thorax width } \mathrm{cm} . . . \\
\text { Plus grande largeur de la carcasse } \\
\text { - au niveau des côtes }\end{array}$ & $23.01 \pm 0.41$ & $22.24 \pm 0.31$ & 1.45 \\
\hline Wth & $\begin{array}{l}\text { Minimum thorax width } \mathrm{cm} . . . \\
\text { Plus petite largeur de la carcasse } \\
\text { au niveau de la } 6^{e} \text { côte }\end{array}$ & $14.93 \pm 0.32$ & $14.41 \pm 0.24$ & 1.26 \\
\hline Th & $\begin{array}{l}\text { Depth (at the sixth } \mathrm{rib} \text { ) } \mathrm{cm} \ldots \\
\text { Plus grande profondeur de la car- } \\
\text { casse au niveau de la } \sigma^{e} \text { côte }\end{array}$ & $24.63 \pm 0.29$ & $25.02 \pm 0.13$ & 1.18 \\
\hline $\mathbf{U}$ & $\begin{array}{l}\text { Thorax girth } \mathrm{cm} . . . . . . . . . . \\
\text { Tour de la carcasse en arrière des } \\
\text { épaules }\end{array}$ & $66.82 \pm 0.65$ & $66.36 \pm 0.41$ & 0.58 \\
\hline F & $\begin{array}{l}\text { Distance perineum-tarsometatarsal } \\
\text { articulation } \mathrm{cm} . . . . . . \ldots \ldots \\
\text { Distance la plus courte entre le } \\
\text { périnée et le bord intérieur de } \\
\text { la surface articulaire tarso- } \\
\text { métatarsienne. }\end{array}$ & $28.54 \pm 0.54$ & $28.56 \pm 0.52$ & 0.03 \\
\hline
\end{tabular}


TABLE 4 (suite)

\begin{tabular}{c|c|c|c|c}
\hline \hline Symbol & Cages & $\begin{array}{c}\text { Litter } \\
\text { Litière }\end{array}$ & $\begin{array}{c}\text { t values } \\
\text { Valeurs de } t\end{array}$ \\
\hline $\mathrm{P}$ & $\begin{array}{c}\text { Distance between the pubic sym- } \\
\text { physis and the tarsometatarsal } \\
\text { articulation cm .......... } \\
\text { La plus grande distance entre le } \\
\text { bord intérieur de la surface arti- } \\
\text { culairé tarso-métatarsienne ei } \\
\text { le bord antérieur de la sym- } \\
\text { physe pubienne } \\
\text { Distance between the pubic sym- } \\
\text { physis and perineum cm .... } \\
\text { La plus grande distance entre le } \\
\text { bord antérieur de la symphyse } \\
\text { pubienne et le point le plus } \\
\text { haut du périnée }\end{array}$ & $37.17 \pm 0.46$ & $37.35 \pm 0.37$ & 0.30 \\
\hline \hline
\end{tabular}

TABLE 5

Carcass dissection

Découpe de la carcasse

\begin{tabular}{|c|c|c|c|}
\hline & Cages & $\begin{array}{l}\text { Litter } \\
\text { Litière }\end{array}$ & $\begin{array}{l}t \text { values } \\
\text { Valeurs de } t\end{array}$ \\
\hline $\begin{array}{l}\text { No. of animals } \ldots \ldots \ldots \ldots \ldots \ldots \ldots \\
\text { Nombre d'animaux }\end{array}$ & 9 & 9 & - \\
\hline $\begin{array}{l}\text { Side weight } \mathrm{kg} \ldots \ldots \ldots \ldots \ldots \ldots \ldots \\
\text { Demi-carcasse }\end{array}$ & $8.62 \pm 0.21$ & $8.19 \pm 0.23$ & 1.36 \\
\hline $\begin{array}{l}\text { Shoulder } \mathrm{g} \ldots \ldots \ldots \ldots \ldots \ldots \ldots \ldots \\
\text { Epaule }\end{array}$ & $1620 \pm 34$ & $1511 \pm 40$ & 2.10 \\
\hline$\underset{\text { Collier }}{\text { Neck }} \mathbf{g} \ldots \ldots \ldots \ldots \ldots \ldots \ldots \ldots \ldots \ldots \ldots$ & $577 \pm 16.5$ & $580 \pm 42.3$ & 0.08 \\
\hline $\begin{array}{l}\text { Rib } g \quad \ldots \ldots \ldots \ldots \ldots \ldots \ldots \ldots \ldots \ldots \\
\text { Carré et poitrine-haut de côtelettes }\end{array}$ & $2578 \pm 79$ & $2436 \pm 88.8$ & 1.20 \\
\hline $\begin{array}{l}\text { Loin } g \quad \ldots \ldots \ldots \ldots \ldots \ldots \ldots \ldots \ldots \\
\text { Filet }\end{array}$ & $732 \pm 84.4$ & $753 \pm 32.8$ & 0.20 \\
\hline $\begin{array}{l}\text { Leg } g \ldots \ldots \ldots \ldots \ldots \ldots \ldots \ldots \ldots \ldots \\
\text { Gigot entier }\end{array}$ & $2899 \pm 77.4$ & $2765 \pm 91.3$ & 1.13 \\
\hline$\underset{\text { Rein }}{\text { Kidney }} \mathrm{g} \ldots \ldots \ldots \ldots \ldots \ldots \ldots \ldots$ & $62 \pm 3.1$ & $62 \pm 1.9$ & 0.07 \\
\hline $\begin{array}{l}\text { Kidney fat } \mathrm{g} \ldots \ldots \ldots \ldots \ldots \ldots \\
\text { Graisse de rognon }\end{array}$ & $78 \pm 9.8$ & $82 \pm 10.3$ & 0.28 \\
\hline
\end{tabular}




\section{c) Carcass measurements}

Several measurements were made in order to evaluate carcass conformation. The values of these measurements are reported in Table IV. Values were quite similar for the two groups and no significant differences were observed.

\section{d) Carcass dissection}

Data from the different cuts obtained from right side dissection tests in male lambs are given in Table $\mathrm{V}$. Noteworthy is the great uniformity of results for both groups. No difference reached statistical significance.

\section{4. - Conclusion}

From the results obtained in the present study it can be concluded that the use of cages with slotted floor in lamb fattening does not affect daily gain and feed intake if compared with traditional straw deep litters. Nor are carcass conformation and composition, as determined by measurements and dissection tests, affected by the different methods of rearing. Further studies will be required to determine the influence of the type of floor on the development of limb bones.

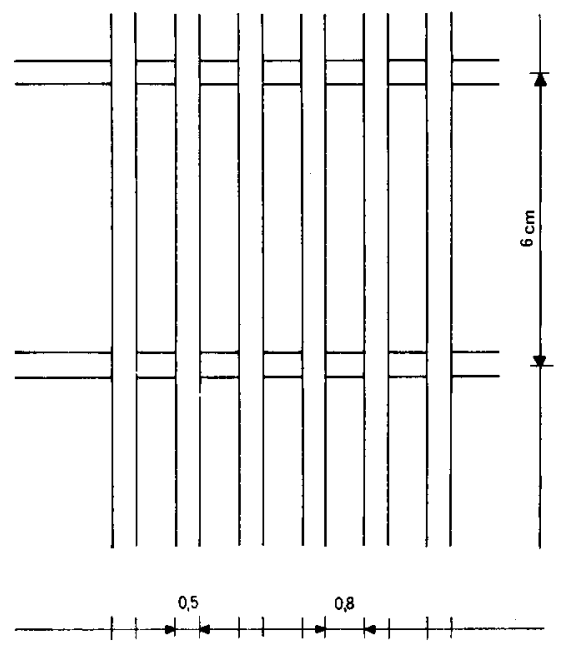

FIG. 2

Particular of the slatted floor

Plancher à claire-voie

Regardless of the management system adopted the results obtained point out the great importance of environmental conditions on fattening lamb performances. 


\section{Résumé \\ Agneaux à l'engrais en cages ou sur litière de paille}

L'expérience a été appliquée à 36 agneaux Suffolk x Appenninica répartis en 6 lots de 6 sujets chacun. Trois groupes ont été élevés dans des boxes sur une litière de paille et 3 en cages avec plancher à claire-voie. Au début des essais, le poids des agneaux était en moyenne de $15 \mathrm{~kg}$ alors qu'à la fin il atteignait environ $35 \mathrm{~kg}$. Par rapport à l'élevage classique sur litière permanente, l'élevage en cage ne modifie ni le gain de poids, ni la consommation d'aliments, ni par voie de conséquence, l'indice de conversion de l'aliment. Le rendement à l'abattage est supérieur chez les agneaux en cage dont la laine est plus propre, ce qui réduit le poids de la peau. $\mathrm{La}$ conformation et la composition de la carcasse, évaluées par mensurations et dissection, ne sont pas affectées par ce mode d'élevage différent. Chez les agneaux élevés en cage le poids des métacarpes est nettement supérieur. Cela pourrait être une conséquence du stress causé par le type de sol sur les os des membres. D'autres recherches s'avèrent utiles pour confirmer ou non cette donnée.

\section{References}

Arehart L.A. Jr., Lewis J.M., Hinds F.C., Mansfield M.E., 1969. Space allowances for lambs on slotted floors. J. Anim. Sci., 29, 638-641.

Boccard R., Dumont B.L., 1955. Etude de la production de la viande chez les ovins. I. La coupe de carcasses. Définition d'une découpe de référence. Ann. Zootech., 4, 241-257.

Boccard R., Dumont B.L., 1976. La qualité des carcasses ovines. $2^{\text {es }}$ Journées de la Recherche ovine et caprine, 1-2 décembre, Paris, Edition I.T.O.V.I.C.-S.P.E.O.C., p. 44.

Boccard R., Dumont B.L., Peyron C., 1964. Etude de la production de la viande chez les ovins. VIII. Relations entre les dimensions de la carcasse d'agneau. Ann. Zootech., 13, 367-378.

Czernek S., Pilarczyk A., 1977. The use of slatted floor for longwool sheep management during a grazing season (polish). Rocz. nauk. Zoot. T., 4, 2.2, 267-274.

Dimitrov D.P., Goranov I., Garanitschewa K., Tanev D., Papuschev E., 1973. Untersuchung über die schafhaltung in Stallräumfn mit spaltenböben. I. Lämmer und jährlingsmast auf spaltenboden. Animal Science, 10, 25-31.

DiRmundsson O.R., 1978. Sheep housing in Iceland. Symposium on sheep housing and Mechanisation in sheep production, Poland, 18-22 September 1978, vol. 1.

Horak F., Novotny M., 1977. The ethology of fattened lambs. Zivočišnâ Vyroba, 23 (1), 53-61.

Macko I., 1976. Fattening lambs in cages. Nás Chov, 36 (5), 208-209. Anim. Breed. Abstr., $1978,46, \mathrm{n}^{\circ} 1834$.

Mansfield M.E., Lewis J.M., McKibBen G.E., 1967. Rearing lambs free of gastrointestinal nematodes. J. Am. Vet. Med. Ass., 151, 1182-1185.

Midwest Plan Service, 1976. Structures and environment handbook. 8th edition, 361-374.

NyGAARD A., 1978. Sheep housing in various climatic condition. Symposium on sheep housing and Mechanisation in sheep production, Poland, 18-22 September 1978, vol. I.

Todorovski N., Risteski K., SaleV M., 1977. Early weaning and fattening in cages of lambs. Stočarstvo, 31 (5-6), 201-208. Anim. Breed Abstr., 1978, 46, n 194.

Warson D.F., 1962. An economical method for producing lambs relatively free from parasites. J. Am. Vet. Med. Ass., 140, 58-60.

WESTENDORP T.J., 1978. Saving on cost of building sheeppens when outlets are realised. Symposium on sheep housing and Mechanisation in sheep production, Poland, 18-22 September 1978, vol. II. 




\title{
Lamb fattening in cages or on straw litter (*)
}

\author{
M. MANFREDINI, C. CAVANI and P. LENZI \\ Istituto di Alimentazione Animale \\ Università di Bologna
}

Via S. Giacomo, 11, 40126 Bologna, Italia

\author{
Summary \\ Lamb fattening in cages or on straw litter
}

\begin{abstract}
The trial was conducted on thirty-six Suffolk x Apennine fattening lambs divided into six groups of six animals each. Three groups were traditionally reared on straw litter and three in slotted-floor cages. The animals averaged $15 \mathrm{~kg}$ at the beginning and approximately $35 \mathrm{~kg}$ at the end of the trial. Slotted-floor cages when compared to on-straw-litter confinement system did not affect daily gain, feed intake and feed efficiency nor they affected carcass traits and composition. Caged animals presented a higher dressing percentage and a higher weight of metacarpi. These results were discussed.
\end{abstract}

\section{1. - Introduction}

The rearing systems used in lamb fattening are continually changing. One of the principal goals of the introduction of modern technology is to save manpower. For this purpose the slatted floor, constructed with different materials, has been tested in pens and in cages (Arehart et al., 1969 ; Dimitrov et al., 1973 ; CzerNeCK \& PilarczyK, 1977 ; NygaArd, 1978 ; Dirmundsson, 1978 ; Westendorp, 1978).

The use of cages in lamb fattening offers many advantages if compared with traditional straw deep litter in that they a) eliminate bedding costs (i.e. costs related to purchase, transport, storage and distribution of straw or other materials); b) require less labour for manure removal; c) reduce space requirements per animal; d) offer clean, dry floor; e) contribute to lamb comforts in hot weather; f) provide better control of parasites (Watson, 1962 ; MANSField, Lewis \& McKibien, 1967). The object of the present experiment is to study the effect of two different rearing systems on fattening lamb performance : fattening in cages and on traditional straw deep litter.

(*) Research carried out in reference to the Progetto Finalizzato del C.N.R. : Incremento delle disponibilita alimentari di origine animale. The present research was in collaboration with the C.R.P.A. (Research Center on Animal Production - Via Crispi, 3 - Reggio Emilia) with partial grant of Regione Emilia Romagna, II Department-Agriculture and Nutrition. 


\section{2. - Material and methods}

Thirty-six Suffolk x Apennine crossbred lambs were used. The animals were divided into 6 groups of 6 individuals each. Three groups were raised on straw litter and three in slotted floor cages. Within each group the lambs were equalized for sex, single or twin lambing, weight and age. They were weaned at 42 days on average, then kept under observation for 5 days before starting the experiment, in order to detect eventual weaning stress and control their adaptability to the new experimental diet.

TABLE 1

Composition of the diet

Composition du régime

\begin{tabular}{|c|c|c|}
\hline $\begin{array}{l}\text { Sorghum meal } \ldots \ldots \ldots \ldots \ldots \ldots \ldots \ldots \ldots \ldots \\
\text { Farine de sorgho }\end{array}$ & $\%$ & 63 \\
\hline $\begin{array}{l}\text { Soyabean meal, solv. } 44 \% \ldots \ldots \ldots \ldots \ldots \ldots \ldots \\
\text { Tourteau de soja }(44 \% \text { prot.) }\end{array}$ & $\%$ & 20 \\
\hline $\begin{array}{l}\text { Condensed carob stillage ..... } \\
\text { Vinasse concentrée de caroube }\end{array}$ & $\%$ & 7,5 \\
\hline $\begin{array}{l}\text { Wheat straw } \ldots \ldots \ldots \ldots \ldots \ldots \ldots \ldots \ldots \ldots \ldots \\
\text { Paille de blé }\end{array}$ & $\%$ & 7 \\
\hline $\begin{array}{l}\text { Dicalcium phosphate } \ldots \ldots \ldots \ldots \ldots \ldots \ldots \ldots \ldots \\
\text { Phosphate bicalcique }\end{array}$ & $\%$ & 1 \\
\hline $\begin{array}{l}\text { Calcium carbonate } \ldots \ldots \ldots \ldots \ldots \ldots \ldots \ldots \ldots \\
\text { Carbonate de calcium }\end{array}$ & $\%$ & 0,5 \\
\hline $\begin{array}{l}\text { Salt } \ldots \ldots \ldots \ldots \ldots \ldots \ldots \ldots \ldots \ldots \ldots \ldots \ldots \ldots \ldots \ldots \\
\text { Chlorure de sodium }\end{array}$ & $\%$ & 0,5 \\
\hline $\begin{array}{l}\text { Mineral-vitamin premix } \ldots \ldots \ldots \ldots \ldots \ldots \ldots \ldots \\
\text { Complément vitaminique et oligo-minéral }\end{array}$ & $\%$ & 0,5 \\
\hline $\begin{array}{l}\text { Analysis : } \\
\text { Composition chimique: }\end{array}$ & & \\
\hline $\begin{array}{l}\text { Dry matter } \ldots \ldots \ldots \cdots \cdots \cdots \cdots \cdots \\
\text { Matière sèche }\end{array}$ & $\%$ & 88,62 \\
\hline $\begin{array}{l}\text { Crude protein } \ldots \ldots \ldots \ldots \ldots \ldots \ldots \ldots \ldots \ldots \\
\text { Matière azotée totale }\end{array}$ & $\%$ of D.M. & 16,95 \\
\hline $\begin{array}{l}\text { Ether extract } \ldots \ldots \cdots \cdots \cdots \cdots \cdots \cdots \cdots \cdots \cdots \\
\text { Matiere grasse }\end{array}$ & $\%$ of D.M. & 2,61 \\
\hline $\begin{array}{l}\text { Crude fibre } \ldots \ldots \ldots \ldots \ldots \ldots \ldots \ldots \ldots \ldots \ldots \ldots \ldots \\
\text { Cellulose brute }\end{array}$ & $\%$ of D.M. & 7,27 \\
\hline $\begin{array}{l}\text { Ash } \\
\text { Minéraux }\end{array}$ & $\%$ of D.M. & 6,05 \\
\hline $\begin{array}{l}\mathrm{N} \text {-free extract } \ldots . . \\
\text { Extractif non azoté }\end{array}$ & $\%$ of D.M. & 67,12 \\
\hline
\end{tabular}




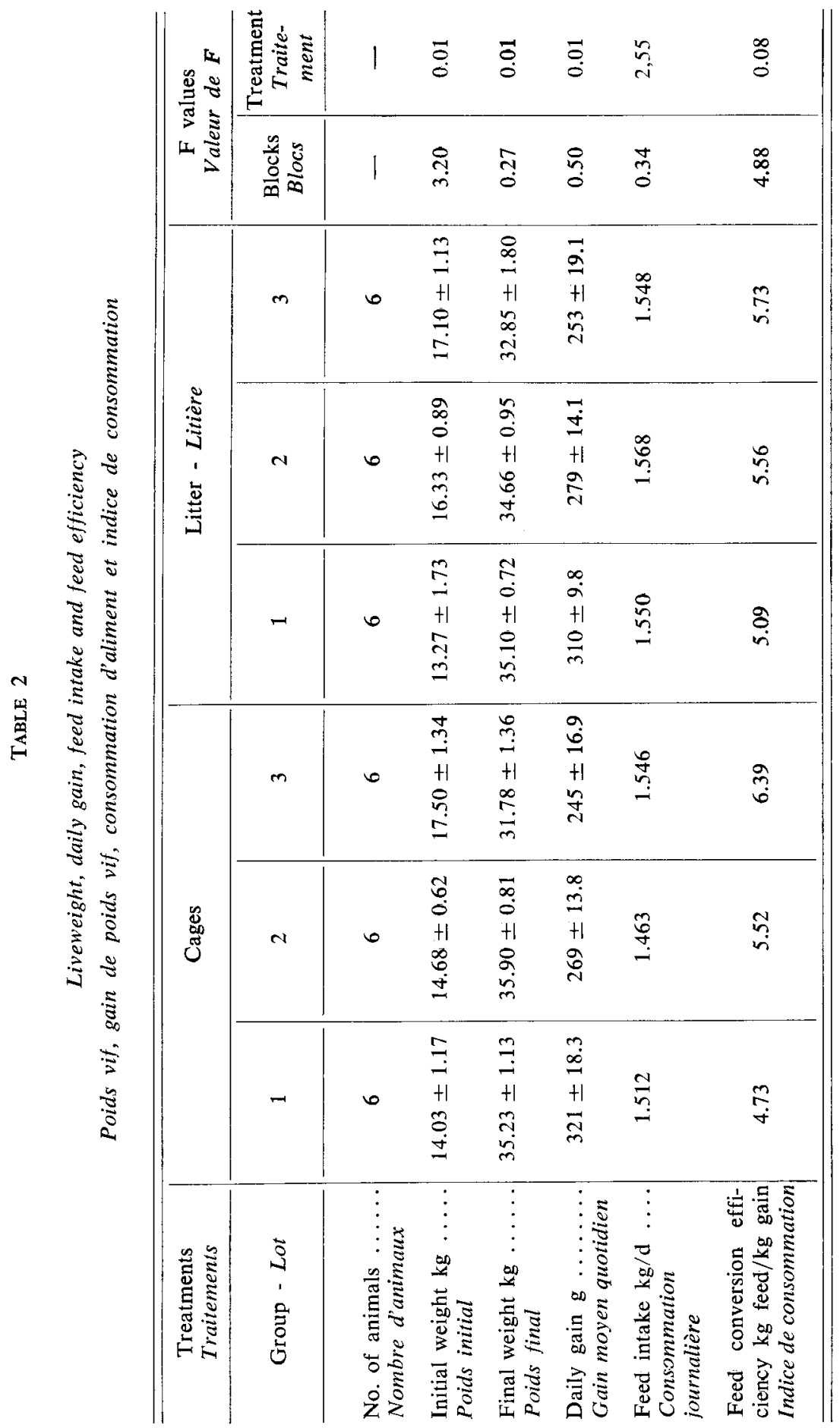




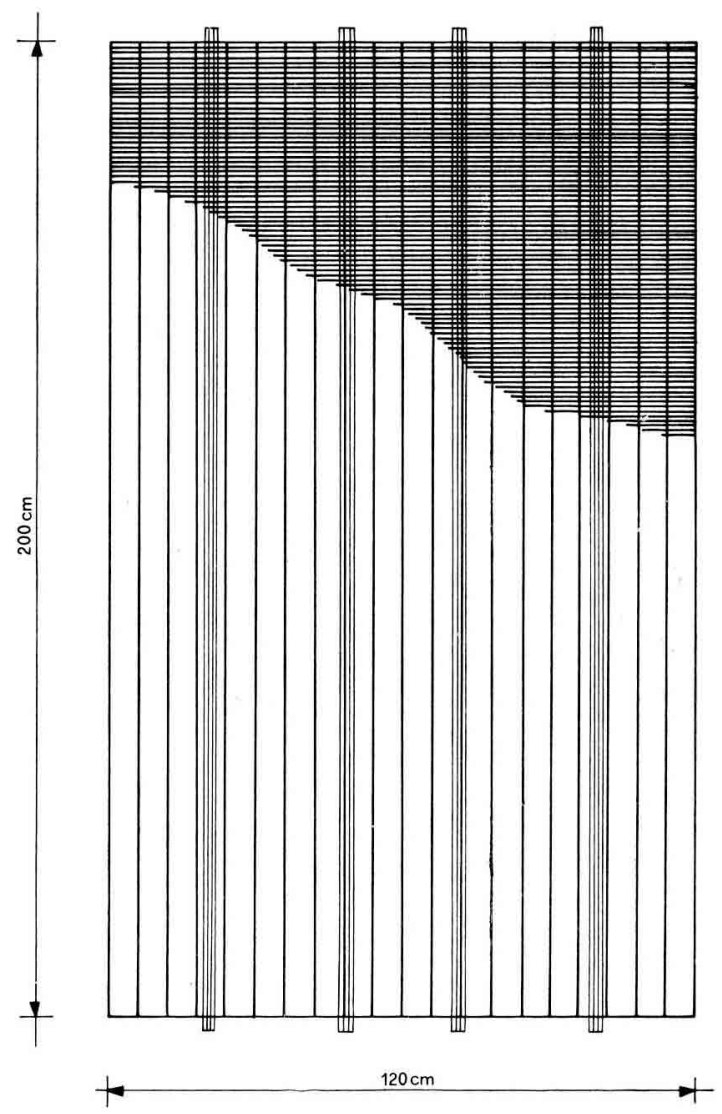

FIG. 1

Sketch of the type of floor used in the cages Type de plancher utilisé dans les cages

\section{a) Slaughter data}

(Table 3) - Dressing percentages, determined both on liveweight and empty body weight, were higher in cage reared lambs. This was mainly due to the higher weight of pelt in the lambs reared on deep litter and attributable to the poorer cleanliness on fleeces.

Also the weight of metacarpi was higher in caged lambs. According to BocCARD \& Dumont (1976) the weight of metacarpi is linked to the development of the skeleton. In this case, however, it is reasonable to assume that the higher development of metacarpi in caged animals is due to the greater stress exerted on the lambs by this kind of floor.

In fact, the research of HORAK \& NOvOTNY (1977) shows that lambs reared on slatted floor spend more time standing, during the day, than those reared on litter (the difference being about three hours). No significant differences were recorded for the other parameters studied. 
The experiment was not begun on the same day for all animals, owing to the difficulty to have 36 suitable subjects simultaneously. The experiment was divided into three successive periods using 12 lambs at a time (two groups). The number 1, 2, 3 are used in Table 2 to indicate the successive groups of lambs used in the experiment.

The cages were made of $200 \times 120 \times 125 \mathrm{~cm}$ metal sections. The space allowance per animal was therefore $0.40 \mathrm{~m}^{2}$. The slotted floors were built from grid sections of $5 \mathrm{~mm}$ electro-welded zinc-coated steel slats and $0.8 \times 5.5 \mathrm{~cm}$ openings. This results in the floors of the cages having a ratio of 56 p. 100 empty space and 44 p. 100 solid surface. Each cage was fitted with a self-feeder on the smaller side and an automatic drinking bowl.

For lambs reared on straw litter, the ground area was $200 \times 170 \mathrm{~cm}^{2}$, i.e. $0.56 \mathrm{~m}^{2}$ per animal. The litters were made up of finely ground straw and were distributed daily in proper amounts so as to avoid the possibility that it might be consumed as food. The lambs were fed ad libitum with a concentrate meal mixture, the chemical composition of which is found in Table 1. Weight gain and feed intake were measured at 21 day intervals. Only male animals were slaughtered for study. These were slaughtered when they reached $35 \mathrm{~kg}$ of liveweight, after 14 hours of fasting.

Carcass measurements were made according to Boccard, Dumont \& Peyron (1964). Complete dissection of right sides was made on the basis of the suggestions of Boccard \& Dumont (1955). The health of the animals were checked daily throughout the experiment to find out clinical symptoms of disease and once again at slaughter by anatomo-pathological examination.

The results were statistically analyzed by analysis of variance and covariance. As concerns data in Table 2, a randomized block experimental design was used.

\section{3. - Results and discussion}

a) Liveweight gain, feed intake and feed efficiency

Table 2 shows that weight gain, feed intake and consequently feed efficiency were not affected by the different rearing systems. The present findings are in agreement with those of american researches reported by the Midwest Plan Service (1976) and with those of MAcko (1976). Similar results were also found by TodoROWSKI, RISTESKI \& SALEV (1977) in an experiment conducted on fattening lambs confined in cages, 5 lambs per cage, for two months.

Conversely, marked differences among the different groups within a same treatment were observed. The groups first placed on test presented weight gains superior to those placed on test later. This phenomenon was observed with both rearing systems. It can be related to the changes in environmental conditions during the experimental period. In fact, the increased number of animals - other lambs were accomodated in the same building together with the experimental ones - as well as the poor ventilation led to a rise in relative humidity and ammonia concentration in the building. 
TABle 3

\section{Slaughter data}

Résultats à l'abattage

\begin{tabular}{|c|c|c|c|}
\hline & Cages & $\begin{array}{l}\text { Litter } \\
\text { Litière }\end{array}$ & $\begin{array}{c}\mathrm{t} \text { values } \\
\text { Valeurs de } t\end{array}$ \\
\hline $\begin{array}{l}\text { No. of animals } \ldots \ldots \ldots \ldots \ldots \ldots \ldots \\
\text { Nombre d'animaux }\end{array}$ & 9 & 9 & \\
\hline $\begin{array}{l}\text { Liveweight } \mathrm{kg} \ldots \ldots \ldots \ldots \ldots \ldots \ldots \ldots \\
\text { Poids vif }\end{array}$ & $35.01 \pm 0.83$ & $34.98 \pm 0.74$ & 0.04 \\
\hline $\begin{array}{l}\text { Empty liveweight } \mathrm{kg} \ldots \ldots \ldots \ldots \ldots \ldots \\
\text { Poids vif vide }\end{array}$ & $32.01 \pm 0.70$ & $31.78 \pm 0.60$ & 0.25 \\
\hline $\begin{array}{l}\text { Carcass weight } \mathrm{kg} \ldots \ldots \ldots \ldots \ldots \ldots \\
\text { Poids de carcasse }\end{array}$ & $17.33 \pm 0.40$ & $16.45 \pm 0.45$ & 1.45 \\
\hline $\begin{array}{l}\text { Carcass wt/live wt } \% \\
\text { Poids de carcasse/Poids vif }\end{array}$ & $49.52 \pm 0.32$ & $47.03 \pm 0.69$ & $3.38 * *$ \\
\hline $\begin{array}{l}\text { Carcass wt/empty live wt } \%, \ldots \ldots \ldots \\
\text { Poids de carcasse/Poids vif vide }\end{array}$ & $54.14 \pm 0.42$ & $51.74 \pm 0.80$ & $2.76^{*}$ \\
\hline $\begin{array}{l}\text { Head (with skin) g } \ldots \ldots \ldots \ldots \ldots \ldots \\
\text { Tête (avec peau) }\end{array}$ & $1917 \pm 36.7$ & $1832 \pm 69.5$ & 1.11 \\
\hline Pelt $g$ Peau (avec laine) & $4520 \pm 192.8$ & $5157 \pm 238.9$ & 2.10 \\
\hline $\begin{array}{l}\text { Feet } \mathrm{g} \ldots \ldots \ldots \ldots \ldots \ldots \cdots \cdots \cdots \cdots \\
\text { Pieds }\end{array}$ & $1025 \pm 28.4$ & $979 \pm 39.4$ & 0.98 \\
\hline $\begin{array}{l}\text { Liver } \mathrm{g} \ldots \ldots \ldots \ldots \ldots \ldots \ldots \ldots \ldots \ldots \\
\text { Foie }\end{array}$ & $679 \pm 21.4$ & $657 \pm 36.1$ & 0.52 \\
\hline $\begin{array}{l}\text { Trachea, lungs, heart, spleen } \mathrm{g} \ldots \ldots \\
\text { Trachée, poumons, cour, rate }\end{array}$ & $1021 \pm 31.9$ & $916 \pm 40.7$ & 2.05 \\
\hline $\begin{array}{l}\text { Testes and scrotum } g \ldots \ldots \ldots \ldots \ldots \\
\text { Testicules et scrotum }\end{array}$ & $147 \pm 15.5$ & $143 \pm 14.5$ & 0.19 \\
\hline $\begin{array}{l}\text { Alimentary tract (empty) } \mathrm{g} \ldots \ldots \ldots \ldots \\
\text { Tube digestif vide }\end{array}$ & $3472 \pm 155$ & $3603 \pm 128.6$ & 0.67 \\
\hline $\begin{array}{l}\text { Metacarpi } \mathrm{g} \ldots \ldots \ldots \ldots \ldots \ldots \ldots \ldots \ldots \\
\text { Métacarpes }\end{array}$ & $117 \pm 3.3$ & $104 \pm 3.2$ & $3.04 * *$ \\
\hline
\end{tabular}


TABLE 4

Carcass measurements

Mensurations de la carcasse

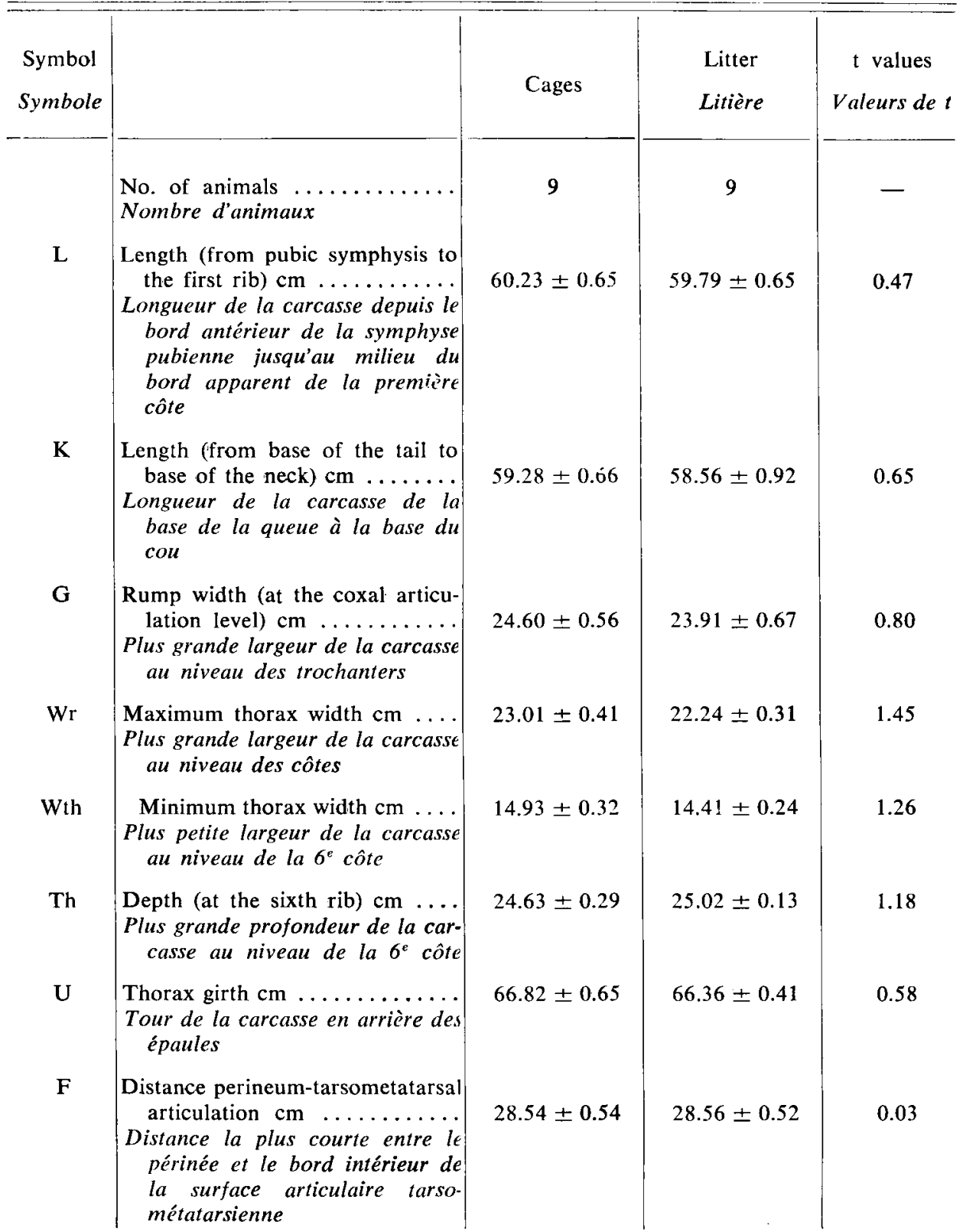


TABLE 4 (suite)

\begin{tabular}{c|c|c|c|c}
\hline \hline Symbol & Symbole \\
\hline $\mathrm{PP}$ & $\begin{array}{c}\text { Cages } \\
\text { Distance between the pubic sym- } \\
\text { physis and the tarsometatarsal } \\
\text { articulation cm ........... } \\
\text { La plus grande distance entre le } \\
\text { bord intérieur de la surface arti- } \\
\text { culaire tarso-métatarsienne et } \\
\text { le bord antérieur de la sym- } \\
\text { physe pubienne } \\
\text { Distance between the pubic sym- } \\
\text { physis and perineum cm .... } \\
\text { La plus grande distance entre le } \\
\text { bord antérieur de la symphyse } \\
\text { pubienne et le point le plus } \\
\text { haut du périnée }\end{array}$ & $10.12 \pm 0.24$ & $\begin{array}{c}\text { t values } \\
\text { Valeurs de t }\end{array}$ \\
\hline
\end{tabular}

TABLE 5

Carcass dissection

Découpe de la carcasse

\begin{tabular}{|c|c|c|c|}
\hline & Cages & $\begin{array}{l}\text { Litter } \\
\text { Litiere }\end{array}$ & $\begin{array}{l}t \text { values } \\
\text { Valeurs de } t\end{array}$ \\
\hline $\begin{array}{l}\text { No. of animals } \ldots \ldots \ldots \ldots \ldots \ldots \ldots \\
\text { Nombre d'animaux }\end{array}$ & 9 & 9 & - \\
\hline $\begin{array}{l}\text { Side weight } \mathrm{kg} \ldots \ldots \ldots \ldots \ldots \ldots \ldots \\
\text { Demi-carcasse }\end{array}$ & $8.62 \pm 0.21$ & $8.19 \pm 0.23$ & 1.36 \\
\hline $\begin{array}{l}\text { Shoulder } \mathrm{g} \ldots \ldots \ldots \ldots \ldots \ldots \ldots \\
\text { Epaule }\end{array}$ & $1620 \pm 34$ & $1511 \pm 40$ & 2.10 \\
\hline $\begin{array}{l}\text { Neck g } \ldots \ldots \cdots \cdots \cdots \cdots \cdots \cdots \cdots \\
\text { Collier }\end{array}$ & $577 \pm 16.5$ & $580 \pm 42.3$ & 0.08 \\
\hline $\begin{array}{l}\mathrm{Rib} g \mathrm{~g} \ldots \ldots \ldots \ldots \ldots \ldots \ldots \ldots \ldots \ldots \ldots \\
\text { Carré et poitrine - haut de côtelettes }\end{array}$ & $2578 \pm 79$ & $2436 \pm 88.8$ & 1.20 \\
\hline $\begin{array}{l}\text { Loin } g \\
\text { Filet }\end{array}$ & $732 \pm 84.4$ & $753 \pm 32.8$ & 0.20 \\
\hline$\underset{\text { Gigot entier }}{\operatorname{Leg} \mathrm{g}}$ & $2899 \pm 77.4$ & $2765 \pm 91.3$ & 1.13 \\
\hline $\begin{array}{l}\text { Kidney } \mathrm{g} \ldots \ldots \ldots \ldots \ldots \ldots \ldots \ldots \ldots \ldots \ldots \\
\text { Rein }\end{array}$ & $62 \pm 3.1$ & $62 \pm 1.9$ & 0.07 \\
\hline $\begin{array}{l}\text { Kidney fat } g \ldots \ldots \ldots \ldots \ldots \ldots \ldots \ldots \\
\text { Graisse de rognon }\end{array}$ & $78 \pm 9.8$ & $82 \pm 10.3$ & 0.28 \\
\hline
\end{tabular}




\section{b) Carcass measurements}

Several measurements were made in order to evaluate carcass conformation. The values of these measurements are reported in Table IV. Values were quite similar for the two groups and no significant differences were observed.

\section{c) Carcass dissection}

Data from the different cuts obtained from right side dissection tests in male lambs are given in Table V. Noteworthy is the great uniformity of results for both groups. No difference reached statistical significance.

\section{4. - Conclusion}

From the results obtained in the present study it can be concluded that the use of cages with slotted floor in lamb fattening does not affect daily gain and feed intake if compared with traditional straw deep litters. Nor are carcass conformation and composition, as determined by measurements and dissection tests, affected by the different methods of rearing. Further studies will be required to determine the influence of the type of floor on the development of limb bones.

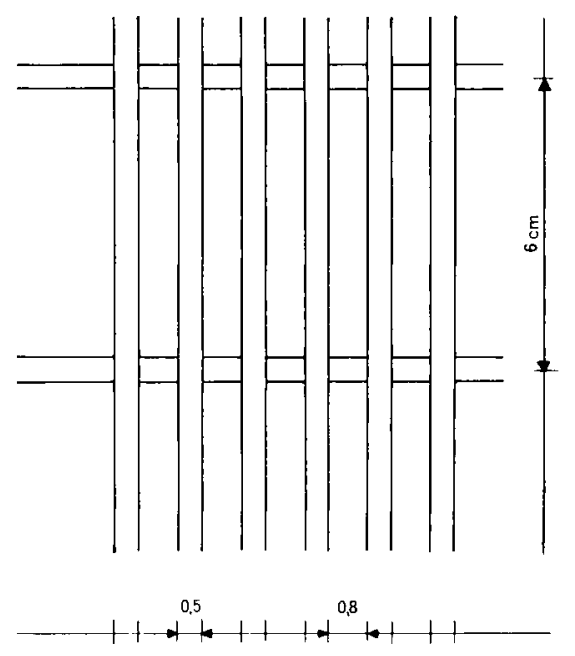

Fig. 2

Particular of the slatted floor Plancher à claire-voie

Regardless of the management system adopted the results obtained point out the great importance of environmental conditions on fattening lamb performances. 


\section{Résumé \\ Agneaux à l'engrais en cages ou sur litière de paille}

L'expérience a été appliquée à 36 agneaux Suffolk x Appenninica répartis en 6 lots de 6 sujets chacun. Trois groupes ont été élevés dans des boxes sur une litière de paille et 3 en cages avec plancher à claire-voie. Au début des essais, le poids des agneaux était en moyenne de $15 \mathrm{~kg}$ alors qu'à la fin il atteignait environ $35 \mathrm{~kg}$. Par rapport à l'élevage classique sur litière permanente, l'élevage en cage ne modifie ni le gain de poids, ni la consommation d'aliments, ni par voie de conséquence, l'indice de conversion de l'aliment. Le rendement à l'abattage est supérieur chez les agneaux en cage dont la laine est plus propre, ce qui réduit le poids de la peau. La conformation et la composition de la carcasse, évaluées par mensurations et dissection, ne sont pas affectées par ce mode d'élevage différent. Chez les agneaux élevés en cage le poids des métacarpes est nettement supérieur. Cela pourrait être une conséquence du stress causé par le type de sol sur les os des membres. D'autres recherches s'avèrent utiles pour confirmer ou non cette donnée.

\section{References}

Arehart L.A. Jr., Lewis J.M., Hinds F.C., ManSField M.E., 1969. Space allowances for lambs on slotted floors. J. Anim. Sci., 29, 638-641.

Boccard R., Dumont B.L., 1955. Etude de la production de la viande chez les ovins. I. La coupe de carcasses. Définition d'une découpe de référence. Ann. Zootech., 4, 241-257.

Boccard R., Dumont B.L., 1976. La qualité des carcasses ovines. $2^{\text {es }}$ Journées de la Recherche ovine et caprine, 1-2 décembre, Paris, Edition I.T.O.V.I.C.-S.P.E.O.C., p. 44.

Boccard R., Dumont B.L., Peyron C., 1964. Etude de la production de la viande chez les ovins. VIII. Relations entre les dimensions de la carcasse d'agneau. Ann. Zootech., 13, 367-378.

Czernex S., Pilarczyk A., 1977. The use of slatted floor for longwool sheep management during a grazing season (polish). Rocz. nauk. Zoot. T., 4, 2.2, 267-274.

Dimitrov D.P., Goranov I., Garanitschewa K., Tanev D., Papuschev E., 1973. Untersuchung über die schafhaltung in Stallräumfn mit spaltenböben. I. Lämmer und jährlingsmast auf spaltenboden. Animal Science, 10, 25-31.

Dirmundsson O.R., 1978. Sheep housing in Iceland. Symposium on sheep housing and Mechanisation in sheep production, Poland, 18-22 September 1978, vol. 1.

Horak F., Novotny M., 1977. The ethology of fattened lambs. Zivočišñâ Vyroba, 23 (1), 53-61.

Macko I., 1976. Fattening lambs in cages. Nás̆ Chov, 36 (5), 208-209. Anim. Breed. Abstr., $1978,46, \mathrm{n}^{\circ} 1834$.

Mansfield M.E., Lewis J.M., McKibBen G.E., 1967. Rearing lambs free of gastrointestinal nematodes. J. Am. Vet. Med. Ass., 151, 1182-1185.

Midwest Plan Service, 1976. Structures and environment handbook. 8th edition, 361-374.

NygaARd A., 1978. Sheep housing in various climatic condition. Symposium on sheep housing and Mechanisation in sheep production, Poland, 18-22 September 1978, vol. I.

Todorovski N., Risteski K., SALEV M., 1977. Early weaning and fattening in cages of lambs. Stočarstvo, 31 (5-6), 201-208. Anim. Breed Abstr., 1978, 46, n 194.

WATSON D.F., 1962. An economical method for producing lambs relatively free from parasites. J. Am. Vet. Med. Ass., 140, 58-60.

WESTENDORP T.J., 1978. Saving on cost of building sheeppens when outlets are realised. Symposium on sheep housing and Mechanisation in sheep production, Poland, 18-22 September 1978 , vol. II. 